\title{
Translation Practice - A Means for Enhancing Student Employability
}

Viorela-Valentina DIMA ${ }^{1}$

\begin{abstract}
Recent studies on employers' expectations regarding the language skills of their employees, as well as the language-related tasks the latter are expected to perform, show that translation activities are essential for everyday business operations. With this in mind, the paper aims to explore the benefits of using translation activities in developing ESP learners' language skills, as well as domain-specific knowledge, so as to meet the demands on the labour market. The case study describes the following steps: student exposure to minimal training in translation steps and strategies, classroom practice on excerpts from economic articles, home translations of full-length economic articles. Feedback exchange on classwork and homework points to the relevance of such activities embedded in Business English lessons: on the one hand, students increase their awareness of language and employabilityrelated aspects; on the other hand, the teacher identifies best practice examples, apart from needs regarding remedial work.
\end{abstract}

Keywords: ESP; language and translation skills; labour market demands; Bucharest University of Economic Studies; Romania

DOI: $10.24818 / \mathrm{DLG} / 2021 / 38 / 13$

\section{Overview of employers' expectations regarding employees' foreign language skills}

$\mathrm{A}$

gainst the background of a highly globalized world, allowing for actual and virtual mobility of workers, as well as for ever increasing use of corporate outsourcing solutions, a lot of attention has been paid to the need for multilingual and multicultural competences at work over the last decade. Several studies have pointed to the benefits of multilingualism and multiculturalism at employee level, at company level, at national and international level: increased business opportunities, increased profit, higher employability and higher wages (cf. for instance

1 Viorela Valentina Dima, Department of Modern Languages and Business Communication, Bucharest University of Economic Studies, Romania, viorela.dima@ase.ro 
Pătru et al. 2018, Dima et al. 2019, Mohanu et al. 2019, and references cited therein). In what concerns the actual use of languages in the workplace, Braddell et al. (2017: 4) define work-related language skills as the skills people need to

- find suitable employment, including language skills for job-search, CV writing, job applications, interviews, etc.

- contribute positively as an employee, including language skills for job specific tasks, health and safety, team working, quality management, customer care, employment rights, responsibilities and processes

- progress at work and develop their career, including language skills for formal workplace training, informal on-the-job learning, further vocational education and training outside the workplace.

Work-related language skills are specific to

- social norms around work - i.e. general expectations around behaviours, ways of communicating, etc. in the context of the world of work

- legislation and regulation, e.g. health and safety law, quality standards

- the communicative demands of the particular field of work - i.e. language

skills required for e.g. engineering, health and social care, retail, IT, etc.

- social norms specific to a particular workplace - i.e. ways of communicating, behavioural expectations, etc.

- the communicative demands of the individual job itself - which will always evolve as circumstances around the job change. (ibidem)

The clarifications in Braddell et al. (2017) complement the Recommendation of the European Parliament and of the Council of Europe on key competences for lifelong learning (2006/962/EC), rendered in Figure 1 below. More specifically, we believe that using languages to perform the work-related tasks cited above proves employees' ability to communicate in their mother tongue and in foreign languages, at the same time contributing to the ongoing development of the first two key competences mentioned in Figure 1 below: 


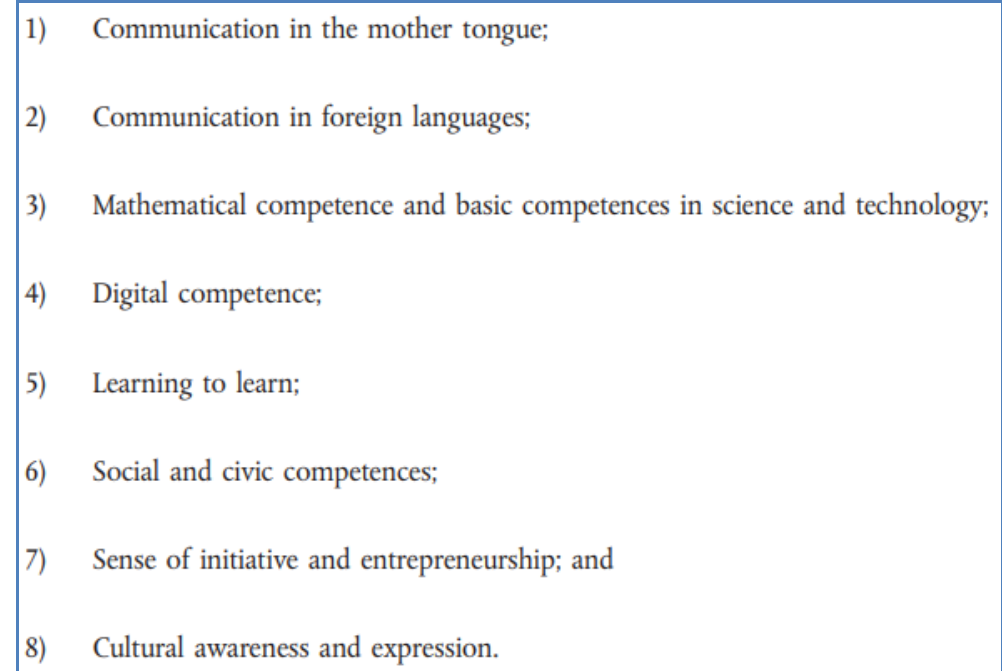

Figure 1. The eight key competences for lifelong learning (apud OJEU 2006, p. 13)

As regards the types of activities European Union citizens use languages for, the Special Eurobarometer 386 (2012: 45-54) mentions both personal and work-related reasons. Among the personal reasons, we mention: "watching films/television or listening to the radio (34\%), on the internet $(34 \%)$ and when communicating with friends $(31 \%)$ ", as well as "reading books, newspapers or magazines (24\%)". Among the work-related reasons, we mention "conversations at work $(25 \%)$ ", "writing e-mails or letters at work", "reading at work", "travelling abroad on business". In what concerns translation activities, they are used (and perceived as important) "in looking for a job, in getting news about events in the rest of the world, participating in or getting news about EU activities and in [...] leisure activities" (idem: 144). The range of contexts translations are used in at work (and not only) is further delineated by Beckers (2019) to include: "development and cooperation, economic and monetary affairs, energy, research and innovation, environment, entertainment, food safety" - see Figure 2 below: 


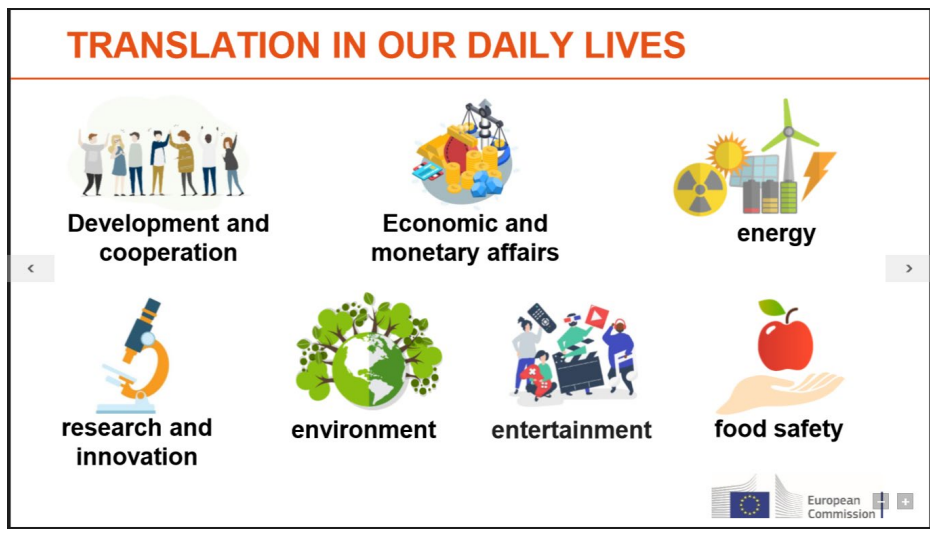

Figure 2. Translation in our daily lives

(apud Beckers, 2019, slide 8)

Companies are increasingly interested in multilingual employees who can use languages at work for a variety of tasks (including translations), as "in-house language skills win clients" (The Guardian, 2014). In-house language services will benefit companies as they help with issues such as: communication with "overseas clients, suppliers and buyers", "understanding a [target] culture", translating product names and characteristics - which eventually leads "to stronger relationships with clients" (idem). Conversely, lacking in-house language services may lead to huge costs (ibidem) ${ }^{2}$.

Along the same lines, the Global Trade Magazine (2020) points to the fact that US companies also value proficiency in a second language "and the cultural awareness that comes with it" (which is expected to trigger higher wages for bilingual workers, as well as "high performance" for "companies of all sizes sourcing talent internationally"). Moreover, the publication estimates "an increase in the request for professional translation services".

The Entrepreneur (2017) also points to the fact that multilingualism benefits people at all levels of the hierarchy: "Whether you're a line-level worker or an expat leading regional operations, language proficiency

2 For exemplification, see Rusu (2017), who investigates the way in which translation quality affects the success of computer games on the Romanian market. More specifically, Rusu (2017: 241) argues that "[m]istranslations, exactly like game bugs, distort the fictional story of the game and interrupt the players' experience, reducing the game impact on the sales market". 
improves your productivity and overall job performance". As for translation activities, the publication also hints at the fact that in-house services are to be preferred, as this will not only save time, but it will also render the company more efficient in delivering brand messages to the markets it targets, and in securing loyal customers who appreciate the time taken to learn the local language and understand the local culture.

With specific reference to work-related translation activities, Holden \& Michailova (2014: 907) point to the fact that

I[nternational] B[usiness] is literally unthinkable and impracticable without translation - every single day, acts of translation, whether formal and informal, accompany or form a central element of an incalculable number of cross-border exchange processes.

Similarly, Nicolae (2014: 62) shows that

The business value [emphasis in original] of the services for translation and interpretation is significant. Communication is the first and main move in a business strategy. Almost nothing can be done in the global market without some type of translation and interpretation among those who intend to set up a business relation. From the large multinational companies to the small businesses and entrepreneurs everybody needs these types of services in various degrees of professionalism and sophistication. The value of business deals and operations is more or less known being reflected in turnover, taxes, value of service to customers etc.; however what is less evident is how much of the success of those operations is due to the translation and interpretation services. And an even more significant indicator is the number of business deals that failed because of lack of good translation and interpretation services.

This section has briefly reviewed a few publications that specifically refer to work-related language skills and translation activities undertaken at work. We have shown that language proficiency is associated with success in business (both at employee level, and at company level) both in Europe and in the United States, and that translation skills are used extensively, alongside other language skills. We now turn to a description of the activities that can be undertaken to develop economics students' translation skills, as conducted by the author of the current article with Accounting and IT students from the Bucharest University of Economic Studies, Romania (henceforth ASE). 


\section{Case study: developing business students' translation skills}

The previous section emphasised the labour market demand for professionals who are highly language proficient, and whose language skills include the ability to translate from and into the 'local' languages of the countries that corporations may find a market in. The publications cited above do not explicitly refer to aspiring translators and interpreters (i.e. those who attend a philological Bachelor's or Master's programme in foreign languages, and subsequent translation certification courses); in fact, regardless of the higher education degree they possess, employees may be expected to make use of and improve their language (and translation) skills for work-related purposes. With this in mind, we would like to discuss how students in economics may be helped to achieve the translation skills that would make them more successful at work.

Before we do so, we would like to briefly touch upon the language (and translation) skills that economics students develop/ make use of during university studies. Thus, as pointed out in Dima et al. (2012) and Dima (2015), economics students from the Bucharest University of Economic Studies (ASE), Romania, use foreign language skills in a number of contexts - during foreign language classes, during economics classes, and during work-related activities (in the case of employed students):

During foreign language classes "[...] students most frequently practice understanding a written text, followed by acquiring specialised vocabulary, understanding a listening text, correspondence writing, essay writing, free oral interaction and translation. The least frequent skill practiced is formal oral interaction (meeting, negotiation etc.)" (Dima 2015: 43).

During economics classes, "foreign languages are used during university years for documentation, understanding economic lectures, writing essays for specialised subjects, making oral presentations and translations" (ibidem).

At work, economics students use foreign languages for "writing business correspondence, [...] documentation, translations and participating in conferences [...], negotiations and making oral presentations, [...] participating in job interviews, participating in professional training programmes, writing job application files" (Dima 2015: 45). 
As evident from the excerpts quoted above, a wide range of skills are practiced during foreign language classes held at ASE, which are of real use both for successful completion of assignments required by economics classes, and for everyday work-related activities. As regards translation activities, foreign language classes allocate the least time for them in comparison to the time allocated for other language skills. Along the same lines, translation skills are the last in order of importance when it comes to the language skills used during economics classes. However, at work, employed students pointed to the fact that translation activities are frequently resorted to, as frequently as documentation skills and participating in conferences, and even more frequently than making oral presentations, among others.

Having established the need for developing economics students' translation skills both for academic and professional success, let us now describe how we approach this task during English for Business seminars taught at ASE's Faculties of Accounting and Management Information Systems (CIG), and Economic Cybernetics, Statistics and Informatics (CSIE). We make reference to classroom activities, homework assignments, and grading by the teacher.

In what concerns classroom activities, each semester, one seminar is dedicated to translation training, based on the textbooks used for English classes with CIG students (Ioncică et al., 2011), and CSIE students (Condruz-Băcescu et al., 2013 and 2014). More specifically, the teacher selects a given one-page reading text in English, divides it into several smaller parts (usually paragraphs) and assigns each part to several pairs of students, for them to translate it into Romanian, following the steps in Table 1 below (cf. Tălmăcian \& Dima 2011: 235):

Table 1. Translation training - Classroom activities

1) produce a word-for-word version of the source text in the target language

2) find creative solutions for lack of equivalents

3) re-write to obtain a natural target language output (from the point of view of vocabulary, grammar and style).

To proceed with the first step, students are allowed to use (online) dictionaries, encyclopaedias, internet search engines, machine translation (Google Translate and similar options), and are encouraged to ask the teacher for help with identifying the denotations of unknown words in the paragraph their pair was assigned to translate. Students forming a pair are 
encouraged to discuss amongst themselves possible connotations and propose solutions for difficult text passages (step 2 above). Afterwards, step 3 is undertaken by the entire class - the pairs who worked on the same paragraph read their versions out loud, while the pairs not working on the respective paragraph are invited to comment on the naturalness of each version ('Does it sound Romanian?') and try to contribute towards making the final version as natural as possible in the target language, and as close as possible to the meaning of the source text. This third step is repeated for each and every paragraph of the text chosen for classroom translation practice. Naturally, the teacher provides both positive and negative feedback - on the one hand, praising creative solutions and, on the other hand, identifying mistakes or inappropriate translation and making suggestions for remedial work.

As concerns homework assignments, the teacher assigns students individual tasks - to translate a short text (up to 200 words) from English to Romanian, and a short text from Romanian to English. The selected texts are usually excerpts from articles published by (general and) economic newspapers and magazines, such as BloombergBusinessweek, The Economist, The Guardian, The Wall Street Journal (for English), and Săptămâna financiară, Ziarul financiar (for Romanian). Students are asked to hand in the assignments at the next seminar (usually the following week), and are provided with feedback on strengths and weaknesses of their translation output roughly two-three seminars later.

Teacher feedback (and grading) focuses on several aspects, as rendered in Table 2 below. Similarly to classroom feedback, homework assignments receive a mixture of negative marking (subtracting points for mistakes), and supportive marking (granting bonus points for creative solutions).

\section{Table 2. Translation training - Evaluation criteria for students' translations}

1) equivalence with the source text
2) lexical and grammatical naturalness in the target language
3) creative solutions for problematic aspects such as collocations, lack of
equivalents
4) accurate rendering of register and style

A note on the theoretical considerations underpinning the choice for the translation activities described above 
Along the lines of Coleman \& Perez (2005), in a previous study, we mentioned that "translation exercises can only lead to sounder language learning" (Tălmăcian \& Dima, 2011: 231). Moreover, years of teaching practice has convinced us that the success of (economics) students as (adhoc) translators is determined both by language knowledge (see Baker, 1992), and by proper choice of translation pedagogy (cf. Cronin, 2005). As such, the translation activities we engage economics students in allow them to become aware of: general translation strategies (both global and local strategies, as suggested by Newmark, 1988, cf also Dumitrescu, 2016 and references cited therein), the usefulness of reference tools (from dictionaries to machine translation), the properties of texts (in our case, articles on economic issues) (cf. Schäffner, 2004). Moreover, we believe peer and teacher feedback (Coleman \& Perez, 2005, Gummerus \& Paro, 2001) is extremely useful in enhancing both language knowledge and translation abilities.

\section{Business students' perceptions of translation activities performed during foreign language classes}

Upon completing each unit from the English for Business textbooks used with economics students, we invited them to complete a feedback questionnaire, so that we may better understand students' perception on what they take away from each unit, in terms of content, language (and transferrable) skills that they feel they have improved/ acquired and areas for remedial work needed, as well as contexts other than the ESP seminars that they believe they can use these skills in. Table 3 below presents the feedback received for the translation activities described in the previous section.

Table 3. Economics students' feedback on translation training activities

\begin{tabular}{|l|l|}
\hline \multirow{3}{*}{ Lesson content } & $\begin{array}{l}\text { "I learned translation steps." } \\
\text { "I learned translation strategies and tools." } \\
\text { "I became aware of the existence of online dictionaries and of } \\
\text { how I can make use of them." } \\
\text { related to my Accounting studies." } \\
\text { "Out of the three steps, the hardest one was step three - making } \\
\text { the text sound as natural as possible in English, or Romanian." }\end{array}$ \\
\hline Language (and & "I learned a lot of new specialized vocabulary."
\end{tabular}




\begin{tabular}{|c|c|}
\hline $\begin{array}{l}\text { transferrable) } \\
\text { skills }\end{array}$ & $\begin{array}{l}\text { "I became aware of [having previously] misunderstood words." } \\
\text { "I learned specialized vocabulary in Romanian." } \\
\text { "I improved writing and grammar skills." } \\
\text { "I can now translate better from English in general." } \\
\text { "I developed the ability to translate texts from English into } \\
\text { Romanian and vice versa." } \\
\text { "The translation activities boosted my confidence when speaking } \\
\text { English." } \\
\text { "I improved communication skills." } \\
\text { "I improved my ability to work in pairs." }\end{array}$ \\
\hline $\begin{array}{l}\text { Remedial work } \\
\text { needed }\end{array}$ & [not mentioned] \\
\hline $\begin{array}{l}\text { Use of } \\
\text { translation } \\
\text { skills outside } \\
\text { the ESP } \\
\text { seminars }\end{array}$ & $\begin{array}{l}\text { Translation skills are useful "on a daily basis at university, as } \\
\text { well as at work in an intercultural environment". } \\
\text { Translation activities are "very useful for my future career". } \\
\text { Translating is "a possible future hobby that I may get paid for". } \\
\text { "I can read and translate economic articles on my own." }\end{array}$ \\
\hline
\end{tabular}

As evident from the learner feedback quoted in Table 3 above, economics students treat translation activities with utmost seriousness and genuinely consider them useful. The minimal exposure to translation theory ${ }^{3}$ is welcomed as an enlightening stage before actually translating the text, as it raises awareness of reference tools and of the need for working on the target version until it becomes sounds natural to the speakers of the respective target language. While performing the classwork and homework translation tasks, economics students identify benefits such as: learning new vocabulary in English (as well as in their mother tongue - Romanian), clarifying vocabulary that was previously acquired but whose meaning was not quite clear, improving grammar and writing skills, and - perhaps surprisingly - improving communication and team work skills. As for the usefulness of translation skills outside the English for Business seminars, economics students believe that having participated in translation training activities has made them more able to meet the demands of university disciplines or future employers.

${ }^{3}$ Mention shoould be made that, during the English for Business seminars described in this paper, we did not make extensive reference to translation studies and scholars in the field, since economics students do not generally aim to become translators. For a study describing how explicit reference to key concepts in translation studies may be undertaken with students enrolled in a translation training programme, see Ardelean (2019). 
Table 3 above does not quote any feedback on remedial work need, as students did not choose to write anything on this issue. However, during the discussions occasioned by the delivery of teacher feedback on homework assignments, students acknowledged their need to further work on steps 2 (use of reference tools) and 3 (fine tuning for naturalness), to read more texts related to their specialisation so that they can improve vocabulary in context in both source and target languages, to improve their knowledge of grammar rules. As for the chosen marking strategy, students appreciated both the negative side (as they generally expect to lose points for mistakes, failures etc.) and the positive side (as they feel it is the equivalent of 'a tap on the shoulder' that recognizes their efforts and encourages them to try again and improve).

All in all, translation activities undertaken with economics students were perceived as "challenging" (occasionally, "terrifying") but also "satisfactory" and "very useful". To our delight, some students also wrote/said "I enjoyed the translation homework", while a few of (the best performing) students find that translating could be a possible career.

\section{Concluding remarks}

The current paper has examined the need for engaging economics students in translation training activities, so that they are better equipped for the labour market. We first reviewed a few publications on workrelated language and translation skills demanded by employers from the European Union and the United States. Next, we focused on the contexts in which economics students from the Bucharest University of Economic Studies (ASE), Romania, use language and translation skills - during foreign language classes, during economics classes, and during workrelated activities. Afterwards, we described the way in which we embark upon translation training through classroom activities and homework assignments, discussing the usefulness of a comprehensive grading scale. Last but not least, a separate section was dedicated to sharing the economics students' opinions on the usefulness of translation training ESP seminars. Based on students' feedback, we conclude that such seminars may indeed contribute to the development of participants' language and translation skills, which are seen as useful for both academic and professional success. 


\section{References}

1. ARDELEAN, C. (2019). "Difficulties in Translating the Political Discourse: an Approach to Specialised Registers", in Synergy 15(1), pp. 51-64, http://www.synergy.ase.ro/issues/2019-vol15-no-1/6-CARMENARDELEAN.pdf

2. BAKER, M. (1992/ 2006). - In Other Words. A coursebook on Translation, Routledge, London and New York

3. BAKER, M. \& SALDANHA, G. eds. (2009). - Routledge Encyclopedia of Translation Studies, 2nd edition, Routledge

4. BECKERS, N. (2019). "Translation - The BIG Picture", Translating Europe Forum 2019, TEF 2019 - Translation all around us. The added value of translation in business and society, https://www.youtube.com/watch?v=FKp-ZKjJuAk\&feature=youtu.be, https://ec.europa.eu/info/events/2019TEF_en

5. BRADDELL, A., GRUNHAGE-MONETTI, M., PORTEFIN, C. and SJOSVARD, K. (2017). Language for work - a quick guide. How to help adult migrants develop work-related language skills. Graz: European Centre for Modern Languages, Council of Europe, https://languageforwork.ecml.at/Portals/48/documents/LFW-quickstart-guide-EN-web.pdf

6. COLEMAN, J. A., PEREZ, I. (2005). “Translating and interpreting”, in COLEMAN, J. A. \& KLAPPER, J. (eds.) (2005), pp. 108-113

7. COLEMAN, J. A. \& KLAPPER, J. (eds.) (2005). Effective Learning and Teaching in Modern Languages, Routledge, London and New York

8. CRONIN, M. (2005). “Deschooling translation: Beginning of century reflections on teaching translation and interpreting", in TENNENT, M., (ed.) (2005), pp. 249-265

9. DIMA, V.V., GHIGA, G., MILITARU, M., ENACHE, A. (2012). “A Case Study on the Impact of English for Special Purposes on Students' Academic and Professional Pursuit", the Knowledge-Based Organization International Conference, Academia Forțelor Terestre, Sibiu, 14-16 June 2012, Conference Proceedings vol. 2, Economic, Social and Administrative Approaches to the Knowledge-Based Organization, Editura Academiei Forțelor Terestre, Sibiu, ISSN 1843-6722, pp. 901904, https://www.researchgate.net/publication/309174945_A_CASE_ STUDY_ON_THE_IMPACT_OF_ENGLISH_FOR_SPECIAL_PURPOS ES_ON_STUDENTS'_ACADEMIC_AND_PROFESSIONAL_PURSUIT 
10. DIMA, V.V. (2015). "The Role of Foreign Language Classes in the Moulding of Professional Economists", in NICOLAE, M. \& CONSTANTINESCU-ȘTEFĂNEL, R. (eds) - The History of Modern Languages in the Bucharest University of Economic Studies. A centennial perspective, ASE Bucharest's Publishing House, Bucharest, 2015, pp. 36-55, http://limbimoderne.ase.ro/docs/public/THE-HISTORY-OFMODERN-LANGUAGES.pdf

11. DIMA, V.V., MOHANU, F., ȘERBAN-OPRESCU, A.T., LORENTZ, M.-A, NICOLAE, R.M. (2019). "Multiculturalism in Romanian Economic Higher Education. Part I - Western Cultural Centres", in Dima, Alina Mihaela (ed.), Sciendo Proceedings. Collaborative Research for Excellence in Economics and Social Sciences. April 4-5, 2019, Bucharest University of Economic Studies, Romania, Proceedings of the $2^{\text {nd }}$ International Conference on Economics and Social Sciences (2019), pp. 173183, Retrieved from https://www.researchgate.net/publication/ 350496007_Dima_et_al_ICESS_2019_Multiculturalism_in_Romanian_ Economic_Higher_Education_Part_I

12. DUMITRESCU, M. (2016). "Landmarks of Translation Studies (A. F. Tytler, M. Arnold and E. Nida). A Critical Evaluation", Synergy 12 (2), pp. 389-397, http://synergy.ase.ro/synergy-vol-12-no-2-2016.html

13. Entrepreneur. (2017). “3 Ways Language Training Benefits Your Business", Ryan McMunn, Entrepreneur, August 7, 2017, https://www.entrepreneur.com/article/296242

14. European Commission. (2012a). Special Eurobarometer 386. Europeans and Their Languages, European Commission, June 2012, Retrieved from https://ec.europa.eu/commfrontoffice/publicopinion/archives/ebs/ebs_ 386_en.pdf

15. European Commission. (2012b). Special Eurobarometer 386. Europeans and Their Languages. Factsheets, European Commission, June 2012, Retrieved from http://ec.europa.eu/languages/documents/ eurobarometer/e386-factsheets-ro_en.pdf

16. GAMBIER, Yves \& GOTTLIEB, Henrik (eds.), (2001). (Multi) Media Translation. Concepts, Practices and Research, John Benjamins, Amsterdam, Philadelphia

17. GONZÁLEZ DAVIES, M. (2004). Multiple voices in the translation classroom: activities, tasks and projects, John Benjamins, Amsterdam, Philadelphia 
18. Global Trade. (2020). “The Most In-Demand Business Language Skills in 2020", Global Trade, Sarah Morris, April 3rd, 2020, https://www.globaltrademag.com/the-most-in-demand-businesslanguage-skills-in-2020/

19. GUMMERUS, E, PARO, C. (2001). “Translation Quality. An Organizational Viewpoint", in GAMBIER, Yves \& GOTTLIEB, Henrik (eds.), 2001, pp. 133-142

20. The Guardian. (2014). "Why language skills are great for business", The Guardian, Lucy Jolin, 16 Dec. 2014, https://www.theguardian. com/small-business-network/2014/dec/16/language-skills-greatbusiness

21. HOLDEN, Nigel J, MICHAILOVA, Snejina. (2014). “A more expansive perspective on translation in IB research: Insights from the Russian Handbook of Knowledge Management", Journal of International Business Studies, volume 45, pp. 906-918

22. MALMKJÆR, K., (ed.) (2004). Translation in Undergraduate Degree Programmes, John Benjamins, Amsterdam, Philadelphia

23. MOHANU, F., DIMA, V.V., NICOLAE, R.M., LORENTZ, M.-A, ȘERBAN-OPRESCU, A.T. (2019). "Multiculturalism in Romanian Economic Higher Education. Part II - Eastern Cultural Centres", in Dima, Alina Mihaela (ed.), Sciendo Proceedings. Collaborative Research for Excellence in Economics and Social Sciences. April 4-5, 2019, Bucharest University of Economic Studies, Romania, Proceedings of the $2^{\text {nd }}$ International Conference on Economics and Social Sciences (2019), pp. 184193, Retrieved from https://www.researchgate.net/publication/ 350495904_Mohanu_et_al_ICESS_2019_Multiculturalism_in_Romania n_Economic_Higher_Education_Part_II

24. NEWMARK, P. (1988). A Textbook of Translation, Hemel Hemstead: Prentice Hall.

25. NICOLAE, M. (2014). "Translation \& Interpretation - The Need for Leadership", in MILITARU, M. \& STANCIU-CAPOTĂ, R. $3^{\text {rd }}$ International Conference Synergies in Communication, Editura ASE, București, pp. 60-63, https://sic.ase.ro/wp-content/uploads/sic2014/pdf-2014/7._Nicolae_2_Translation_and_interpretation._The_ need_for_leadership.pdf

26. OJEU. (2006). "Recommendation 2006/962/EC of the European Parliament and of the Council of 18 December 2006 on key competences for lifelong learning", Official Journal of the European Union, pp. 10-18, https://eur-lex.europa.eu/legal-content/EN/TXT/ PDF/?uri=CELEX:32006H0962\&from=EN 
27. PĂTRU, C., LORENTZ, M.-A, DIMA, V.V., MOHANU, F., HURDUZEU, R.-E. (2018). Lifelong Learning for the Labor Market, in DUMITRESCU, D, ZAMFIR, A. (coord.). 2018. Proceedings of the 1st International Conference on Economics and Social Sciences, Filodiritto Publisher, inFOROmatica srl, Via Castiglione, 81, 40124 Bologna (Italy), pp. 334-342, Retrieved from http://icess.ase.ro/index.php/icess2018/icess-2018-proceedings

28. RUSU, O. (2017). “Translating Video Games into Romanian: Yay or Nay?", in MILITARU, M. (coord.) 6th International Conference: Synergies in Communication, Editura ASE, București, pp. 241-246, https://sic.ase.ro/wp-content/uploads/sic-2017/pdf-2017/RusuOlivia.2_Translating-video-games.pdf

29. SCHÄFFNER, C. (2004). "Developing professional translation competence without a notion of translation", in MALMKJÆR, Kirsten, ed. (2004), pp. 113-125

30. TĂLMĂCIAN, E., DIMA, V.V. (2011). "Issues in the translation/ adaptation of economic terms", in CILIANU-LASCU, C. (coord.) Buletin ştiinţific, nr. 8, Actes de la Conférence Internationale La formation en terminologie, 3-4 novembre 2011, Editura ASE, Bucureşti, pp. 230-240

31. TENNENT, M., (ed.). (2005). Training for the New Millennium, Amsterdam: John Benjamins

\section{Translation texts taken from:}

1. CONDRUZ-BĂCESCU, M., DIMA, V.V., DONA, D., DUMITRESCU, V. M., TĂLMĂCIAN, E. (2013). Ahead in Business English, Editura Universitară, București

2. CONDRUZ-BĂCESCU, M., DIMA, V.V., DONA, D., DUMITRESCU, V. M., TĂLMĂCIAN, E. (2014). Business English. Practice and Progress, Editura Universitară, București

3. IONCICĂ, D., CALCIU, R., DONA, D., DIMA, V.V. 2011, Practical English for Finance and Accounting, Editura Uranus, Bucureşti

BloombergBusinessweek, https://www.bloomberg.com/businessweek

Săptămâna financiară, https://www.sfin.ro/

The Economist, https://www.economist.com/

The Guardian, www.theguardian.com

The Wall Street Journal, https://www.wsj.com/

Ziarul financiar, www.zf.ro 